\title{
Seeking Meaning: The Educationally Critical Aspect of Learning About Information Systems
}

\author{
Chris Cope \\ La Trobe University, Bendigo, Australia
}

c.cope@latrobe.edu.au

Abstract

The research reported in this paper investigated and compared the experience of learning about the concept of an information system (IS) at a scholarly, and an undergraduate level. A scholarly level learning experience was developed from the literature and represented a benchmark against which students' learning experiences could be compared. A group of undergraduate students' learning experiences were investigated in an empirical, phenomenographic study. An awareness and understanding of the process of seeking meaning was found to be an educationally critical aspect of a deep approach to learning about IS and a deep understanding of the concept of an IS. The finding has important implications for teaching and learning about IS. Learning tasks can be designed which aim to enhance learning through focussing students' awareness simultaneously on the IS conceptual and learning aspects of seeking meaning. An example of the use of rich pictures to achieve this aim is given.

Keywords: IS education, student perspectives, phenomenographic research, information systems, learning approaches

\section{Introduction}

This paper summarises a study that compared the experience of learning about the concept of an information system (IS) at a scholarly and an undergraduate level. The aim was to identify any aspects of the learning experience that were educationally critical to the development of a depth of understanding of the concept of an IS appropriate for graduates. The study was significant in that educationally critical aspects of learning about the concept of an IS have not been researched previously. Yet, without emphasising and addressing these aspects in teaching and learning the development of an appropriate depth of understanding is unlikely.

\section{Theoretical Background}

The notion that successful learning experiences have identifiable, educationally critical aspects has been developed in the work of Booth (1994, 1997), Cope (2000a), Marton (1998) and Marton and Booth (1996, 1997). Underlying the notion are 3 consistent findings of studies into student learning which have used phenomenographic research approaches. This section describes the nature of phenomenographic research;

Material published as part of these proceedings, either on-line or in print, is copyrighted by Informing Science. Permission to make digital or paper copy of part or all of these works for personal or classroom use is granted without fee provided that the copies are not made or distributed for profit or commercial advantage AND that copies 1) bear this notice in full and 2) give the full citation on the first page. It is permissible to abstract these works so long as credit is given. To copy in all other cases or to republish or to post on a server or to redistribute to lists requires specific permission from the publisher atpublisher@intormingscience.org overviews the 3 consistent findings; presents the analytical tool developed from the findings which was used to investigate IS learning experiences; and develops the notion of educationally critical aspects. 


\section{Phenomenographic Research Approaches}

Phenomenographic research approaches were developed in the early 1970s to qualitatively investigate the different ways in which groups of individuals conceptualised, perceived or understood phenomena in the world (Marton, 1981). Phenomenographic research takes a second order research perspective - the focus is on analysing other peoples' accounts of their experiences of phenomena. Data is commonly collected from small groups of people through individual, in-depth, semi-structured interviews about a particular phenomenon. The interview transcripts are combined and analysed to identify and describe the distinctly different ways in which the phenomenon is experienced by the group. Many phenomenographic studies have investigated phenomena associated with students' learning experiences. These phenomena include the different levels of understanding of a concept, topic or course; the different ways learning can be approached; and the relationship between learning approach and level of understanding. Three major insights into student learning obtained from phenomenographic studies of learning experiences have contributed to the theoretical notions that underlie the study reported here.

\section{Three Key Insights Into Student Learning}

\section{A particular concept, topic or course area can be understood in a limited num- ber of qualitatively different ways}

The results of many phenomenographic studies have shown that a phenomenon can be understood in a limited number of qualitatively different ways (for example Johansson, Marton, \& Svensson, 1985; Lybeck et al., 1988; Prosser \& Millar, 1989; Cope, 2000a). Of considerable importance, the research has found that the different ways of understanding a phenomenon are related in a hierarchy of depth of understanding based on logical inclusiveness. Deeper levels of understanding of a phenomenon are inclusive of shallower levels of understanding. An example to demonstrate these findings is a study of the different ways of understanding mathematics as a course area in the questionnaire responses of 300 first year undergraduate students (Crawford et al., 1994). A hierarchy of five different levels of understanding of mathematics was identified. The lowest level of understanding represented a fragmented view of mathematics as numbers, rules and formulae. The deeper levels described a more complex view of mathematics as a means of solving complex problems and developing new insights used for understanding the world. The deeper understandings were found to be inclusive of the lower levels of understanding. Students who experienced mathematics as a means of solving complex problems were aware that numbers, rules and formulae were the tools used to solve problems. Students who only experienced the study of mathematics as learning rules and formulae had a view of mathematics that would limit them in terms of solving complex problems they had not experienced before.

\section{Students approach learning in a limited number of qualitatively different ways}

The second of the major insights into student learning concerns students' approaches to learning. Students' experiences of their own approaches to learning have been studied empirically both qualitatively and quantitatively (for example Biggs, 1988; Entwistle \& Ramsden, 1983; Marton \& Säljö, 1976; Svennson, 1984). Many of the qualitative studies used phenomenographic research techniques. Two qualitatively different approaches to learning have been consistently identified. These approaches are known as surface and deep learning approaches.

A surface approach to learning is characterised by a student completing a task as perceived without attributing meaning to the task. A typical intention of a student adopting a surface approach is short-term memorisation of the content associated with a learning task for later reproduction in assessment situations. Each learning task is focused on in isolation. Booth (1997) describes a typical surface approach as rotelearning the facts and algorithms suited to solving the characteristic questions asked at the time. A deep 
approach, in contrast, seeks meaning in a task through trying to relate the task to other tasks and/or existing understanding and/or personal experience. A deep approach focuses on developing a cohesive whole through seeking relationships between the various tasks, existing understanding and experiences. It is the cohesive whole which is considered to represent understanding (Entwistle, 1998).

\section{The quality of students' learning outcomes is related to the learning approach adopted}

The finding of statistically significant relationships between students' learning approaches and learning outcomes is the third of the major insights into student learning in higher education to which phenomenographic studies have contributed. The nature of any relationship between level of understanding of a phenomenon and approach to learning has been studied qualitatively and quantitatively at both task and topic level (for example Crawford et al., 1994; Hazel, Prosser \& Trigwell, 1996; Marton \& Säljö, 1976; Prosser \& Millar, 1989). Surface learning approaches have been found to be more likely to lead to the development of lower levels of understanding of a phenomenon. Deep learning approaches have been found to open up the possibility of the development of deeper levels of understanding.

\section{A Model of an Experience of Learning About a Phenomenon}

The three insights into student learning have been combined by Marton and Booth (1997) to develop a model for analysing and understanding an individual's experience of learning about a phenomenon. The experience can be analysed and described in terms of related "what" and "how" aspects. The "what" aspect concerns the level of understanding of the phenomenon developed as a consequence of the learning experience. The "how" aspect concerns the approach used to learn about the phenomenon. While the "what" and "how" aspects of a learning experience are inseparable in practice, the different aspects can be analysed separately and the relationship between the aspects investigated to describe and understand the experience as a whole.

\section{The Notion of Educationally Critical Aspects}

The significance of Marton and Booth's (1997) model of a learning experience is that students learning about a phenomenon will be undergoing a learning experience consisting of related "what" and "how" aspects. The findings of many phenomenographic studies suggest the existence of distinct qualitative variation in the "what" and "how" aspects. Given that the "what" and "how" aspects of a learning experience have been found to be related, it follows that distinct variation in learning experience is likely. Some learning experiences will be better (more successful) than others. Those learning experiences involving a deep learning approach are more likely to lead to deeper levels of understanding. The notion then arises of aspects of the experience of learning about a phenomenon in which there are critical differences between better and poorer learning experiences. These aspects are educationally critical to the development of a deep understanding of the phenomenon. Knowledge of these educationally critical aspects allow specific, targeted learning tasks to be designed which are more likely to encourage the development of deep understanding.

\section{Method}

In the previous section the notion and importance of identifying educationally critical aspects of the experience of learning about a phenomenon was considered. A review of the relevant literature indicates that the educationally critical aspects of the experience of learning about the concept of an IS at an undergraduate level are not known. This section describes the method of a study that sought to address this vital lack of knowledge 
There were three sections to the study. The first section aimed to describe a scholarly level experience of learning about the concept of an IS. This scholarly learning experience was derived from the IS education and general student learning research literature and was designed to be a benchmark against which undergraduate IS students' experiences could be compared. The second section involved an empirical, phenomenographic study of the learning experiences of a group of undergraduate IS students. The third section combined the findings of the first two sections of the study to describe variation in experience of learning about the concept of an IS. An analysis of this variation lead to the identification of the educationally critical aspects of learning about the concept of an IS.

The empirical study of undergraduate students' experiences of learning about the concept of an IS was undertaken at La Trobe University, Bendigo, Australia, between 1997 and 1999. The detailed method, including justification of validity and reliability, is available in Cope (2000a). An overview and brief description of the method will be given here.

The study was designed to give multiple insights into the experiences of students learning about IS for a year in the Bachelor of Computing at La Trobe University, Bendigo. An intensive aspect of the study involved in-depth, semi-structured interviews with a small number of students. An extensive aspect involved short-answer questionnaires completed by a large number of students. The participants in the study were initially recruited for the extensive aspect. From this pool of participants volunteers were sought for the intensive aspect. Questionnaires involving short written answers were completed in lectures at the beginning, middle and end of the year of study about IS. One hundred and twelve students completed at least one questionnaire during the year. Interviews were held at the beginning and end of the year of study about IS. Twenty-three students were interviewed during the year, fifteen of those twice. The questionnaires and interview guide questions are available in Cope (2000a).

Analysis of the data occurred in two stages. First, the interview transcripts were combined to form a large pool of decontextualised statements about the experience of learning about the concept of an IS. The pool of statements was analysed using a phenomenographic approach to investigate the "what" and "how" aspects of the learning experiences. Hierarchies of distinctly different levels of understanding of the concept of an IS ("what" aspect) and approaches to learning about IS ("how" aspect) were developed. An example of the analysis as applied to the "what" aspect of the learning experience will be given. The researcher considered the view of an IS which underlay each statement in the pool in order for the statement to make sense. Questions asked about each statement included "of what aspects of an IS is the utterer of the statement aware?", "how are the aspects conceptualised?", "what relationships are inferred between the aspects of an IS?", and "what scope does an IS have within an organisation?". Statements with similar underlying views of an IS were grouped. The basis for the grouping was a distinctly different understanding of an IS. Distinct differences lay in the number of aspects comprising an IS, the depth of understanding of the aspects, the relationships between aspects and the scope of an IS in an organisation.

Over an extended period of analysis the groups of statements were compared and contrasted to refine the distinct differences and to establish any relationships between the levels of understanding. Finally the level of understanding of an IS underlying each group of statements was given a label, described and illustrated with statements from the pool. A similar analysis process was applied to statements concerning approach to learning about IS

The second stage of data analysis was concerned with investigating any relationship between the "what" and "how" aspects. Each interview transcript and questionnaire was classified against the hierarchies of level of understanding of the concept of an IS and approach to learning about IS. The classification process involved deciding which level of the appropriate hierarchy best underlay each interview transcript and questionnaire as a whole. Multiple researchers were used in classifying the transcripts and questionnaires as part of establishing the reliability of the data analysis. 
The classification data was analysed statistically to explore the existence and nature of any relationship between level of understanding of the concept of an IS and approach to learning about IS. The two variables were cross tabulated and exact statistical techniques (Babinec \& Mehta, 1999) were used to investigate relationships.

\section{Results}

\section{A Scholarly Experience of Learning About the Concept of an IS}

The nature of the experience of learning about the concept of an IS of an exemplary undergraduate scholar was described, based on a review of the literature. The experience is described in terms of "what" and "how" aspects and the relationship between them.

\section{"What" aspect}

This aspect concerns the nature of a deep understanding of the concept of an IS appropriate for new graduates as prospective IS professionals. The level of understanding described was developed from a review of textbook definitions, journal articles and the reports of task groups, in particular Alter (1999), Clarke (1992), Wand and Weber (1995), Winter, Brown and Checkland (1995), Land (1992), BeynonDavies (1998), Falkenberg et al. (1996) and the many publications of IFIP WG 8.2.

To contribute productively to the successful development of information systems in modern organisational contexts new graduates need to view an IS as a social system in which decision making is supported by embedded IT. Given the rapid expansion of information systems within and across organisations, including across continents, the scope of an IS needs to be conceptualised as incorporating multiple, interrelated organisational functions. The IT captures, stores, maintains, organises and outputs data in a formal, organised way, and assists with the efficiency of informal data flow within the organisation and direct observation of resources. The people and the processes they perform are part of the IS. In particular, people attribute meaning to the formal and informal data they receive from the system and make decisions based on the meaning. Attribution of meaning is a term coined by Checkland and Holwell (1998) and involves making sense in the organisational context of the data output by the IT parts of the system. There also needs to be an awareness that in modern information systems some meaning attribution, assistance with decision making and actual decision making can be performed by the IT. A full justification for this view of a deep understanding of the concept of an IS is available in Cope (2000a).

\section{"How" aspect}

The nature of an approach to learning about the concept of an IS likely to be adopted by a scholarly undergraduate student receives little attention in the IS education research literature. The general student learning research literature suggests that a specific deep learning approach would be necessary to develop the deep understanding outlined in the previous section. This learning approach would involve students actively seeking different perspectives on the concept of an IS in a variety of active, cooperative, experiential learning tasks, and in personal experiences (Cope \& Horan, 1996; Godfrey, 1995; Lu, 1994; Thomson, 1994; Wagner, 1997). Through reflecting on the different perspectives, the meaning inherent in each learning activity needs to be related to the meaning inherent in other learning activities in the same subject, in related subjects and in personal experiences. As part of this deep learning approach students also need to reflect on their own and others' levels of understanding of an IS and approaches to learning about IS. The development of a deep understanding of the concept of an IS needs to be an explicit intention of the student. Undergraduate students need to actively intend to develop the related set of aspects of an IS which constitute the deep understanding. It is this intention which initiates and drives the seeking of meaning with regard to the concept of an IS. 


\begin{tabular}{|c|c|c|}
\hline Level & Label & Description \\
\hline 6 & $\begin{array}{l}\text { A number of communicating informa- } \\
\text { tion systems within a single organisation }\end{array}$ & $\begin{array}{l}\text { All people, computer hardware, data and information } \\
\text { related processes associated with communicating in- } \\
\text { formation systems within a single organisation. The } \\
\text { relationships between and within the different aspects } \\
\text { of the IS are not well understood. }\end{array}$ \\
\hline 5 & $\begin{array}{l}\text { A computerised data manipulation sys- } \\
\text { tem and all the people and the data- } \\
\text { related procedures they perform to sup- } \\
\text { port a single organisational function. }\end{array}$ & $\begin{array}{l}\text { Data collection procedures, multiple data inputs, mul- } \\
\text { tiple processes, multiple information outputs, infor- } \\
\text { mation dissemination procedures. All people in- } \\
\text { volved with generating or collecting input, input of } \\
\text { data, generation of output or dissemination of output. } \\
\text { All people who receive and use information from the } \\
\text { system. Computer hardware and software. }\end{array}$ \\
\hline 4 & $\begin{array}{l}\text { A computerised data manipulation sys- } \\
\text { tem supporting many people within a } \\
\text { single organisational function. }\end{array}$ & $\begin{array}{l}\text { Multiple data inputs, multiple processes, multiple } \\
\text { information outputs and a dynamic database. Com- } \\
\text { puter hardware and software. Understanding of the } \\
\text { data manipulation processes remains poor. There is } \\
\text { some understanding that the database is structured } \\
\text { rather than a mass of undifferentiated data. }\end{array}$ \\
\hline 3 & $\begin{array}{l}\text { A data manipulation system supporting } \\
\text { an individual within a single organisa- } \\
\text { tional function }\end{array}$ & $\begin{array}{l}\text { Initial input of data to a database, input of data to } \\
\text { keep the database current, a dynamic database, re- } \\
\text { quests for information, processing of the relevant data } \\
\text { to form the required information and the output of } \\
\text { information. Sometimes computer hardware and } \\
\text { software. Understanding of the nature of the process- } \\
\text { ing, the structure of the database and the relationship } \\
\text { between them is weak. }\end{array}$ \\
\hline 2 & A simple information retrieval system. & $\begin{array}{l}\text { A database, a query on the database, a process which } \\
\text { extracts the relevant data from the database and an } \\
\text { output. The relationships between the different as- } \\
\text { pects of the IS and the structure within the aspects are } \\
\text { poorly discerned. }\end{array}$ \\
\hline 1 & $\begin{array}{l}\text { A personal search of a static information } \\
\text { source }\end{array}$ & A static source of information and a personal search \\
\hline
\end{tabular}

Table 1: Levels of understanding of the concept of an IS

\section{Relationship between the "What" and "How" aspects}

The results of many phenomenographic studies of students' learning experiences have established empirically that the "what" and "how" aspects of the experience are related. It seems logical then, that in an IS education context, the "what" and "how" aspects of the scholarly learning experience are related. Only through approaching learning about IS in the manner described is the development of an appropriate deep understanding of the concept of an IS likely. 


\section{Variation in a Group of Undergraduate Students' Experiences of Learning About the Concept of an IS}

\section{"What" aspect}

Six distinctly different but hierarchically related levels of understanding of the concept of an IS were identified in the phenomenographic study of the interview transcripts and questionnaire responses of IS students at La Trobe University, Bendigo (Cope, 2000a; 2000b). The levels of understanding are summarised in Table 1. Levels of understanding higher in the hierarchy (level 6) are inclusive of and represent a deeper understanding of the concept of an IS than those lower in the hierarchy. Levels of understanding higher in the hierarchy involve an awareness of more related aspects of an IS and delimit an IS as a much broader entity within an organisation. Levels of understanding 1 through 4 represent IT-only views of an IS. Levels of understanding 5 and 6 incorporate people in the IS, one aspect of an IS as a social system.

\section{"How" aspect}

Two distinctly different approaches to learning were identified in the interview transcripts and are described below.

Learning Approach 1 - Acquiring knowledge associated with isolated aspects of the content with the intention of being able to recall or apply that knowledge in assessment situations.

In this approach, learning about IS was experienced as a series of isolated and generally unrelated learning and assessment tasks which had to be completed successfully to satisfy academic achievement requirements and academic progress. Each learning task was experienced as a potential source of knowledge that needed to be acquired to meet the assessment requirements. Knowledge was variously experienced as facts contained in lecture notes and summaries, formulae, how and when to apply formulae, tactics to solve problems, skills, how to use software, etc. There was variation in the experience of acquiring this knowledge. Acquiring knowledge was construed as either an active, intentional process of memorising the content or a less active process of gaining knowledge through absorbing the content, having it sink in, taking it in. There was also variation in how the acquired knowledge was to be recalled or applied in assessment situations. In some instances the intention was to be able to directly recall the knowledge. In other instances, the intention was to be able to apply memorised procedures, problem solving approaches, software instructions, etc.

A quote from student DF gives an example typical of this approach.

What would you do in lectures in those subjects?

I mainly take down any notes that the lecturer puts down on overheads and that's where I mostly get my information from. It can be very hard to write down what the lecturer is saying - so I mainly get the information from the overheads and I write that down and mainly skip over what the lecturer is saying because I'm concentrating on the overheads.

Why do you make that choice?

Because it's easier to get the information from the overheads than the actual lecturer, because if you're writing down what the lecturer is saying you can easily miss information or misinterpret information - whereas if it's on the overhead the information is already there and is easy to get down and you know you won't misinterpret it because what's written there will be what's written on your sheet of paper as well. So basically it comes down to you not wanting to misinterpret what the lecturer says and you don't want to miss out on information.

Why is it important not to miss out on information?

It will affect my results.

How do you use the information from the overheads?

I use the information in any assignments we get and the exam - that's basically it. 
Learning Approach 2 - Seeking the meaning of the content with the intent of developing or deepening understanding.

In this approach, learning about IS involved a process of seeking the meaning of the content encountered in learning tasks and assignments. The learning and assignment tasks were not seen as external impositions - merely hurdles to be jumped in the race to obtain a degree. Rather they involved some content that had a meaning beyond the immediate task. The learning experience included a motivation to seek this meaning as a part of learning in the academic setting and for personal reasons beyond the academic setting. Meaning was sought in the learning and assignment tasks by relating them to other aspects of the same course's content or the content of other courses (both IS courses and other computing courses). The intention of the learning approach was to develop or deepen understanding. There was variation in the experience of having an understanding. In some instances, an understanding meant having a clear picture, a completed puzzle, a scenario, one's own version of the content. In other variations, an understanding formed a background that could be used to link new material or allowed a concept to be explained to others off the top of the head. In yet other variations an understanding meant knowing when and how to apply concepts in new situations with competency.

The following quote from student EOD illustrates seeking meaning within an academic setting.

\footnotetext{
How do you know when you have understood something?

Because you can use the information somewhere else, to help your understanding of another point, sort of like the way I see it is some puzzle and you've got all these pieces of the puzzle and you gradually pull them into the puzzle.

So we're putting together pieces of a puzzle?

Yeah. And when you put the puzzle together you've got understanding.

So how do you use that puzzle?

Yeah, like to understand other topics like one piece of information leads to another and like in maths, you can't, well I can't learn algebra without learning factors and terms, you've got to learn that first and then you can go onto...

What happens say if, say with an information system where you have no background knowledge at all, and the lecturer starts talking about them, how do you go with the puzzle then?

Um, I guess I'd call upon other computer knowledge um, and try and make sense of it as best I can, but you've got to understand that when I first came to Uni, I had no idea of computers at all so it's like I've learnt a lot since then even though I had no prior knowledge.
}

Learning Approach 1 represents a typical surface approach and Learning Approach 2, a typical deep approach, as described in many studies reported in the literature. Based on intention, the two approaches are mutually exclusive. The intention of Learning Approach 1 is to consider aspects of the content in isolation. The intention of Learning Approach 2 is to look for links between the aspects of content. Logically, these intentions cannot exist simultaneously. Learning Approach 2, the deep approach, is a more complex and desirable learning approach.

\section{Relationship Between the "What" and "How" Aspects}

The overall finding of the statistical investigation of the classifications of the questionnaires and interviews conducted at the end of the year of study about IS was a significant statistical association (Table 2). For the group of students studied, the deep approach to learning about IS (Learning Approach 2) was associated with the development of the deeper levels of understanding of the concept of an IS (Levels 5 and 6). The surface learning approach (Learning Approach 1) was associated with the shallower levels of understanding of the concept of an IS (Levels 1 through 4). This finding supports similar relationships found in published phenomenographic studies of students' experiences of learning about other phenomena. 


\begin{tabular}{|c|c|c|c|c|c|c|c|}
\hline \multirow{2}{*}{$\begin{array}{l}\text { Learning ap- } \\
\text { proach }\end{array}$} & \multicolumn{6}{|c|}{ Level of understanding of the concept of an IS } & \multirow[b]{2}{*}{ Totals } \\
\hline & 1 & 2 & 3 & 4 & 5 & 6 & \\
\hline \multicolumn{8}{|c|}{ End questionnaire } \\
\hline Surface & & 11 & 27 & 13 & & & 51 \\
\hline Deep & 1 & & 1 & 4 & 2 & & 8 \\
\hline Total & 1 & 11 & 28 & 17 & 2 & & 59 \\
\hline \multicolumn{8}{|c|}{ Kendall's tau-b $=.295, \mathrm{p}=.015$} \\
\hline \multicolumn{8}{|l|}{ End interview } \\
\hline Surface & & & 4 & 6 & 2 & & 12 \\
\hline Deep & & & & & 1 & 2 & 3 \\
\hline Total & & & 4 & 6 & 3 & 2 & 15 \\
\hline
\end{tabular}

Table 2: Relationship between level of understanding of the concept of an IS developed and approach to learning about IS

\section{Variation in Experience of Learning About the Concept of an IS}

The investigation of scholarly and undergraduate experiences of learning about the concept of an IS identified three distinctly different learning experiences (Table 3).

\section{Discussion and Conclusion}

\section{Comparison Between the Scholarly and Undergraduate Experiences of Learning About the Concept of an IS}

The scholarly learning experience was a benchmark, developed from current research knowledge, against which students' learning experiences could be compared. Educationally critical aspects of the experience of learning about the concept of an IS are those aspects of the scholarly learning experience that are critical to the development of a deep understanding of the concept of an IS. To determine the critical aspects required identifying the critical differences between the scholarly and students' experiences. A detailed analysis of the differences is reported in Cope (2000a). Here the 3 experiences (Table 3) are compared in terms of their "what", "how" and relationship between "what" and "how" aspects to identify the key difference and, hence, identify the key educationally critical aspect of the experience of learning about the concept of an IS. All differences are determined in the light of the scholarly experience.

\section{"What" aspect}

The deep understanding of the concept of an IS that forms the "what" aspect of the scholarly learning experience views an IS as a social system supported by embedded IT. The people in the system attribute meaning to various sources of organised and unorganised data prior to decision making. Because people will interpret data differently any IS development project needs to understand how the people in an organisation attribute meaning and how this meaning drives action. From Land's (1992) perspective this 
requires an IS developer to be aware that people need information delivered differently depending on their prior knowledge and cognitive style and environmental and situational factors. To ensure people are considered in IS development projects it is prudent to include people and the attribution of meaning process as part of an IS.

The students' levels of understanding 1 through 4 have no awareness of any social aspects of an IS. Levels 5 and 6 incorporate people in the IS but involve little awareness of the functions the people perform. The critical difference between the scholarly and student understandings of an IS, and a key to the development of a deep understanding, is an awareness of the process of attribution of meaning as a human activity and the need to incorporate this process and people undertaking this process in the concept of an IS.

\section{"How" aspect}

A surface and a deep learning approach were identified in the student data. The learning approach associated with the scholarly learning experience is a more sophisticated deep approach than the deep learning

\begin{tabular}{|l|l|l|l|}
\hline Experience & \multicolumn{1}{|c|}{ "What" aspect } & "How" aspect & $\begin{array}{l}\text { Relationship } \\
\text { between as- } \\
\text { pects }\end{array}$ \\
\hline Scholarly & $\begin{array}{l}\text { Understanding of an IS as social } \\
\text { system of people attributing } \\
\text { meaning to varied sources of data } \\
\text { as a precursor to meaningful deci- } \\
\text { sion making. The organisation of } \\
\text { the data and in some instances the } \\
\text { attribution of meaning and deci- } \\
\text { sion making are supported by IT } \\
\text { embedded in the system }\end{array}$ & $\begin{array}{l}\text { Scholarly deep approach - } \\
\text { intention to develop a deep } \\
\text { understanding through inten- } \\
\text { tionally seeking varied per- } \\
\text { spectives on the concept of } \\
\text { an IS. Includes an awareness } \\
\text { of the experience of learning } \\
\text { about IS. }\end{array}$ & $\begin{array}{l}\text { Logically } \\
\text { significant }\end{array}$ \\
\hline Student A & $\begin{array}{l}\text { Understanding of an IS as people } \\
\text { and IT supporting a number of } \\
\text { interrelated organisational func- } \\
\text { tions }\end{array}$ & $\begin{array}{l}\text { Student deep approach - re- } \\
\text { lating of learning tasks to } \\
\text { other learning tasks. Inten- } \\
\text { tion to seek meaning in } \\
\text { learning tasks as a means of } \\
\text { developing or deepening un- } \\
\text { derstanding }\end{array}$ & $\begin{array}{l}\text { Empirically } \\
\text { significant }\end{array}$ \\
\hline Student B & $\begin{array}{l}\text { Understanding of an IS as an IT } \\
\text { (data manipulation) system of } \\
\text { varying complexity and scope }\end{array}$ & $\begin{array}{l}\text { Surface approach - focus on } \\
\text { learning tasks in isolation. } \\
\text { Intention to commit content } \\
\text { to memory for later repro- } \\
\text { duction }\end{array}$ & $\begin{array}{l}\text { Empirically } \\
\text { significant }\end{array}$ \\
\hline
\end{tabular}

Table 3: Distinctly different experiences of learning about the concept of an IS

approach identified in the student data. A broader range of perspectives on an IS is used and there is a greater awareness of the experience of learning about IS. Both deep approaches are likely to lead to a deepening of understanding of the concept of an IS. The surface learning approach is not. The critical difference between the surface and deep learning approaches lies in the intentional process of seeking meaning relevant to the concept of an IS through relating learning tasks to other learning tasks, both in the same subject and in other subjects. This seeking of meaning is part of both deep approaches but not an aspect of the surface learning approach. The educationally critical aspect of approaching learning about the concept of an IS is the process of seeking meaning. 
In considering the "what" and "how" aspects of the experience of learning about the concept of an IS as a whole, the key educationally critical aspects are an awareness of the processes of attributing and seeking meaning. These two aspects of the learning experience can be shown to be describing the same process. The term used by Checkland and Holwell (1998) to describe the process of a person interpreting the organised data that is the output of a computerised data manipulation system was "meaning attribution". The process of meaning attribution is described as "We relate it (the capta) to other things, we put it in a context, we see it as part of a larger whole which causes it to gain in significance" (p.89). The term "seeking of meaning" is often used in descriptions of a deep approach to learning. Prosser and Trigwell (1999, p.3) describe seeking meaning as "... making the task coherent with their own experience ... integrating the task with existing awareness ... seeing the parts of a task as making up a whole ...". With only a deep approach to learning likely to lead to the development of a deep understanding of the concept of an IS as a social system, the process of seeking or attributing meaning is a key educationally critical aspect of the experience of learning about the concept of an IS.

\section{Implications for Teaching and Learning About the Concept of an IS}

The path to the development of a deep understanding of the concept of an IS is a deep learning approach in which students seek the meaning of what they are being taught. How do we encourage students to use deep learning approaches? Attempts to directly instruct students in the techniques of deep learning approaches have been successful only when the instruction is linked to a particular content area (Marton \& Booth, 1997). Consequently, Marton and Booth (1996) believe that thematising both the approach and content of learning in teaching is the overarching principle for encouraging deep learning approaches and achieving quality learning outcomes. Students need to be aware not only of the content they are learning but also the approaches they are using to learn about the content. IS curriculum designers and teachers have a considerable pedagogical advantage in trying to implement this axiom. The key educationally critical aspects of a deep understanding of the concept of an IS and an effective approach to learning about IS are the same process - seeking of meaning.

In an IS education context an opportunity exists to design and use active, co-operative, experiential learning tasks which encourage students to be aware of the equivalence of the process of attribution of meaning in an IS context and seeking of meaning in a deep approach to learning. At La Trobe University, Bendigo, we use two learning activities to achieve this aim. Firstly we provide students with a report from an IS and give them a decision to make based on the data on the report. A good example, based on Säljö (1991), is the older style table used by the postal service to calculate the price to send a parcel a certain distance (Table 4). Each student is asked to calculate the price to send a certain weight parcel a certain

\begin{tabular}{|c|c|c|c|c|}
\hline \multicolumn{5}{|c|}{ Postal rates for parcels (\$) } \\
\hline \multirow{4}{*}{$\begin{array}{c}\text { Distance (kms) } \\
\text { (not exceeding) }\end{array}$} & \multicolumn{4}{|c|}{$\begin{array}{c}\text { Weight (gms) } \\
\text { (not exceeding) }\end{array}$} \\
\cline { 2 - 5 } & 50 & 250 & 500 & 1000 \\
\hline 50 & 1.70 & 3.40 & 6.00 & 10.50 \\
\hline 250 & 2.25 & 4.50 & 8.00 & 14.50 \\
\hline 500 & 4.50 & 9.00 & 16.00 & 28.00 \\
\hline 1000 & 7.50 & 15.00 & 26.00 & 46.00 \\
\hline
\end{tabular}

What would it cost to send a $150 \mathrm{gm}$ parcel a distance of $375 \mathrm{kms}$ ?

Table 4: Learning task to demonstrate attribution of meaning in IS context 
distance. The calculations are collated. Typically a number of different prices have been calculated. Why this is the case is then discussed. The lecturer facilitates the discussion with two points in mind. The report is not information. It is organised data. In determining a price for the parcel the students were attempting to attribute meaning to the organised data on the report. People attribute meaning in different ways. In conceptualising information systems it is important to understand how the potential users of a report attribute meaning as this will influence the design of the report.

The second learning task tries to thematise IS content and learning simultaneously and focus on the process of seeking meaning as part of developing an understanding. We get students to draw rich pictures of their conception of the courses they are studying. Rich pictures are an IS development documentation tool designed by Checkland (1981) as part of his soft systems philosophy. Rich pictures are used to seek the meaning of problem domains in organisational contexts. The pictures portray relevant aspects of an organisational context as icons. Relationships between aspects of the contexts are recorded with arrows and the relationships are named.

We use rich pictures to encourage students to think about the important aspects of the content of a course, the approaches to learning they are using and the relationships within the content and between the content and the learning. Figure 1 is a student's rich picture of his/her learning experience in the course IS Practice, a third year course in the Bachelor of Computing at La Trobe University, Bendigo, Australia.

We talk to students about the process of drawing rich pictures. We point out that the pictures cannot be drawn as part of surface learning approaches. We make students aware that in drawing rich pictures, in thinking about icons which appropriately illustrate an aspect of the picture, in thinking about which aspects are related and naming the relationships, they are seeking meaning and creating an understanding. We then ask students to contrast in written form the processes of attribution of meaning in an IS content context and seeking meaning in an IS learning context. Importantly we ask students to show their writing to other students. This provision of different perspectives on the experience of learning about IS is an important aspect of the scholarly approach to learning about IS.

\section{Future research}

The context of the empirical study reported in this paper was limited. Students' learning experiences were investigated in two introductory IS subjects in the Bachelor of Computing at La Trobe University, Bendigo, Australia. It is likely that only some of the possible variation in undergraduates' experiences of learning about the concept of an IS was identified. Hence there is no guarantee that all of the educationally critical aspects of the learning experience became evident. Similar research to that reported in this paper would be of value investigating the learning experiences of students who had been studying about the concept of an IS in other countries, for a longer time and at different educational levels. 


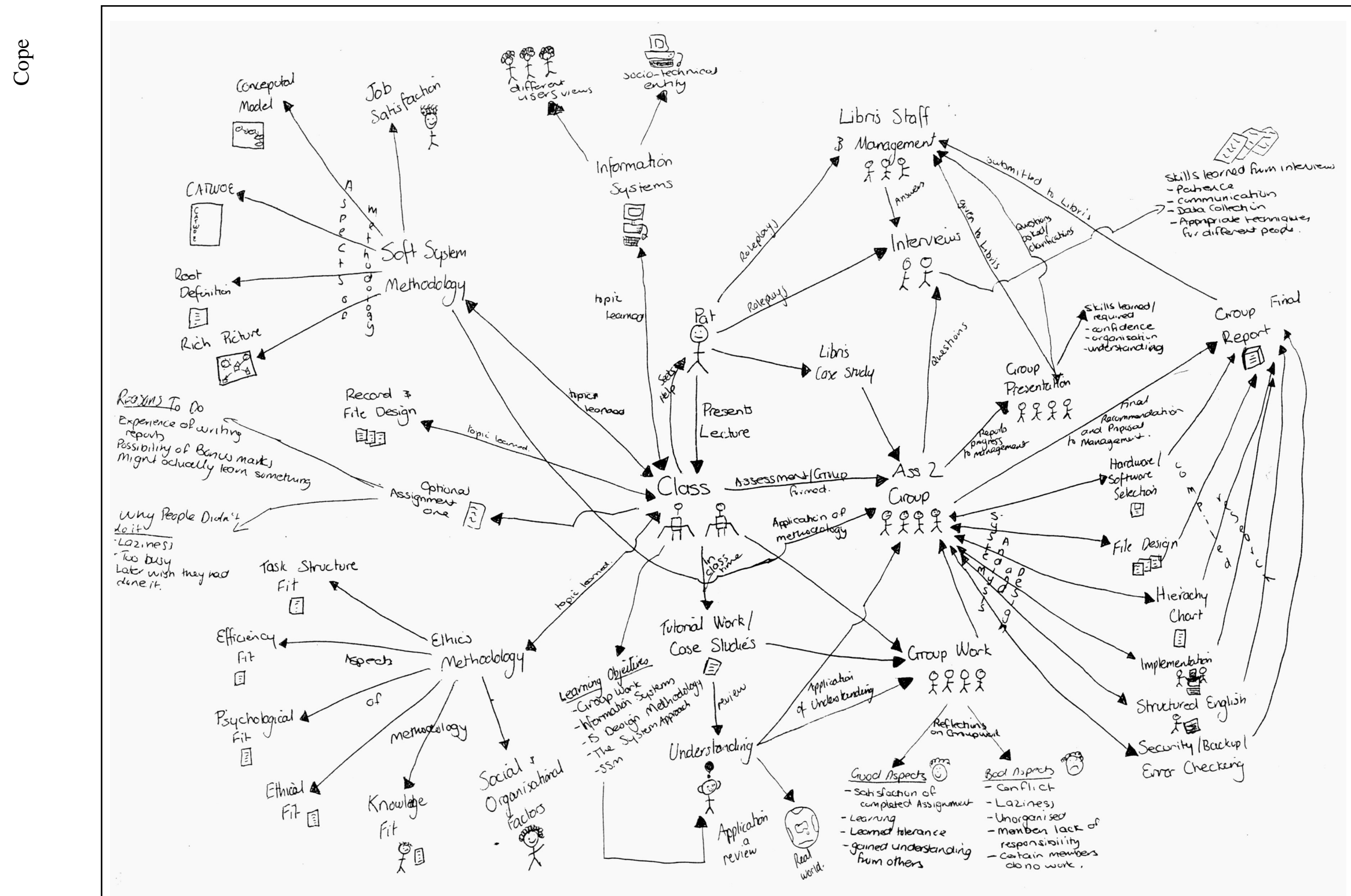

Figure 1: Student's rich picture of their experiences of the course IS Practice 


\section{Reference List}

Alter, S. (1999). A general, yet useful theory of information systems, Communications of the Association for Information Systems, [On-line journal] 1, article 13. Available: http://cais.isworld.org/contents.asp

Babinec, T., \& Mehta, C. (1999). Exploring exact statistics. [On-line]. Available: http://www.spss.com/newsltrs/kw/Kw58/StatSpeak.html.

Biggs, J.B. (1988). Assessing student approaches to learning. Australian Psychologist, 23, 197-206.

Booth, S.A. (1994). On phenomenography, learning and teaching, In R. Ballantyne \& C. Bruce (Eds.), Proceedings of Phenomenography: Philosophy and Practice (pp.3-6). Brisbane, Queensland: QUT Publications and Printing.

Booth, S.A. (1997). On phenomenography, learning and teaching. Higher Education Research and Development, 16 (2), 135 157.

Beynon-Davies, P. (1998). Information systems development ( $3^{\text {rd }}$ ed.). London: MacMillan Press.

Checkland, P. (1981). Systems Thinking, Systems practice. Chichester, UK: Wiley.

Checkland, P., \& Holwell, S. (1998). Information, systems and information systems - making sense of the field. England: Wiley.

Clarke, R. (1992). Extra-organisational systems: A challenge to the software engineering paradigm. Presented at the IFIP World Congress, Madrid, September. [On-line] Available: http://www.anu.edu.au/people/Roger.Clarke/SOS/PaperExtraOrgSys.html

Cope, C.J. (2000a). Educationally critical aspects of the experience of learning about the concept of an information system. $\mathrm{PhD}$ thesis [On-line]. Available: http://ironbark.bendigo.latrobe.edu.au/staff/cope/Chris.Cope.html

Cope, C.J. (2000b). Educationally critical aspects of a deep understanding of the concept of an information system. Proceedings of the Fourth Australasian Computing Education Conference, Monash University, 4 - 6 December 2000.

Cope, C.J., \& Horan, P. (1996). The role played case: An experiential approach to teaching introductory information systems development. Journal of Information Systems Education, 8 (2\&3), 33-39.

Cope, C.J., \& Horan, P. (1998). Towards an understanding of teaching and learning about information systems. The Proceedings of the Third Australian Conference on Computer Science Education (pp. 188-197), New York: ACM.

Crawford, K., Gordon, S., Nicholas, J., \& Prosser, M. (1994). Conceptions of mathematics and how it is learned: The perspectives of students entering university. Learning and Instruction, 4, 331-345.

Entwistle, N. J. (1998). Improving teaching through research on student learning. In J.F.F Forest (Ed.), University teaching: international perspectives. New York: Garland Publishing.

Entwistle, N. J., \& Ramsden, P. (1983). Understanding student learning. London: Croom Helm.

Falkenberg, E.D., Hesse, W., Lindgreen, P., Nilsson, B.E., Han Oei, J.L., Rolland, C., Stamper, R.K., Van Assche, F.J.M., Verrijn-Stuart, A.A., \& Voss, K. (1996). A Framework of Information Systems Concepts. Report of the IFIP WG 8.1 Task Group FRISCO.

Godfrey, R.M. (1995). Students as end-users: Participative design of the I/S learning experience. Journal of Computer Information Systems, 36 (1), 17-22.

Hazel, E., Prosser, M., \& Trigwell, K. (1996). Student learning of biology concepts in different university contexts. Research and Development in Higher Education, 19, 323-326.

Johansson, B., Marton, F., \& Svensson, L. (1985). An approach to describing learning as change between qualitatively different conceptions. In A.L. Pines \& L.H.T. West (Eds.), Cognitive structure and conceptual change (pp. 233-258). New York: Academic Press.

Land, F. F. (1992). The information systems domain. In R. Galliers (Ed.), Information systems research: issues, methods and practical guidelines (pp. 6-13). Oxford, UK: Blackwell Scientific Publications.

Lu, H. (1994). A preliminary study of student responses to different CIS course teaching strategies, Journal of Computer Information Systems, 34 (4), 31-36.

Lybeck, L., Marton, F., Stromdahl, H., \& Tullberg, A. (1988). The phenomenography of the "Mole Concept" in chemistry. In P. Ramsden (Ed.), Improving learning. New perspectives (pp. 81-108). London: Kogan Page. 
Marton, F. (1981). Phenomenography - describing conceptions of the world around us. Instructional Science, 10, $177-200$.

Marton, F. (1998). Towards a theory of quality in higher education. In B.Dart \& G. Boulton-Lewis (Eds.), Teaching and learning in higher education (pp. 177-200). Camberwell, Vic., Australia: Australian Council for Educational Research.

Marton, F., \& Booth, S. (1996). The learner's experience of learning. In D.R. Olson \& N. Torrance (Eds.), The handbook of education and human development: New models of learning, teaching and schooling (pp.534-564). Oxford: Blackwell.

Marton, F., \& Booth, S. (1997). Learning and awareness. Mahwah, NJ: Erlbaum.

Marton, F., \& Saljo, R. (1976). On qualitative differences in learning. I. Outcome and process. British Journal of Educational Psychology, 46, 4-11.

Prosser, M., \& Millar, R. (1989). The how and what of learning physics. European Journal of Psychology in Education, 4, 513-528.

Prosser, M., \& Trigwell, K. (1999). Understanding learning and teaching: the experience in higher education. Philadelphia, PA: Society for Research into Higher Education \& Open University Press.

Säljö, R. (1991). Learning and mediation: Fitting reality into a table. Learning and Instruction, 1, 261-272.

Svensson, L. (1984). Skill in Learning. In F. Marton, D. Hounsell, D. \& N.J. Entwistle (Eds.), The experience of learning (pp. 56-70). Edinburgh: Scottish Academic Press.

Thomson, N.S. (1994). Using TQM principles to teach current topics in information systems. Journal of Information Systems Education, 6 (2), 65-72.

Wand, Y., \& Weber, R. (1995). On the deep structure of information systems. Information Systems Journal, 5, $203-223$.

Wagner, W. P. (1997). Teaching information systems concepts using World-Wide Web-Based content. Journal of Computer Information Systems, 38 (2), 76-81.

Winter, M.C., Brown, D.H., \& Checkland, P.B. (1995). A role for soft systems methodology in information systems development. European Journal of Information Systems, 4, 130-142.

\section{Biography}

Dr. Chris Cope is an academic in the Department of Information Technology at La Trobe, University, Bendigo, Australia. His research interests concern clarifying the nature of an information system and identifying the aspects of an information system that are critical to the development of a deep understanding. 